\title{
BURST FRACTURE OF THE THORACOLUMBAR SPINE: CORRELATION BETWEEN KYPHOSIS AND CLINICAL RESULT OF THE TREATMENT
}

\author{
FRATURA DA COLUNA TORACOLOMBAR TIPO EXPLOSÃO: CORRELAÇÃO ENTRE CIFOSE \\ E RESULTADO CLÍNICO DO TRATAMENTO
}

\author{
FRACTURA DE LA COLUMNA TORACOLUMBAR DEL TIPO EXPLOSIÓN: CORRELACIÓN \\ ENTRE CIFOSIS Y RESULTADO CLINIICO DEL TRATAMIENTO
}

Rodrigo Arnold Tisot ${ }^{1}$, Juliano da Silveira Vieira ${ }^{1}$, Renato Tadeu dos Santos ${ }^{1}$, Augusto Alves Badotti ${ }^{1}$, Diego da Silva Collares ${ }^{1}$, Leonardo Domingues Stumm¹, Bruno Brum Barreto', Paulo Bruno Camargo ${ }^{2}$

\begin{abstract}
Objective: To evaluate the correlation between kyphosis due to burst fractures of thoracic and lumbar spine and clinical outcome in patients undergoing conservative or surgical treatment. Methods: A retrospective, cross-sectional study was conducted with 29 patients with thoracolumbar burst fractures treated by the Spine Group in a trauma reference hospital between the years 2002 and 2011. Patients were followed-up as outpatients for a minimum of 24 months. All cases were clinically evaluated by Oswestry and SF-36 quality of life questionnaires and the visual analogue scale (VAS) of pain. They were also evaluated by X-ray examinations and CT scans of the lumbosacral spine at the time of hospitalization and subsequently as outpatients by Cobb method for measuring the degree of kyphosis. Results: There was no statistically significant correlation between the degree of initial kyphosis and clinical outcome measured by VAS and by most of the SF-36 domains in both patients treated conservatively and the surgically treated. The Oswestry questionnaire showed benefits for patients who received conservative treatment $(p=0.047)$ compared to those surgically treated $(p=0.335)$. The analysis of difference between initial and final kyphosis and final kyphosis alone in relation to clinical outcome showed no statistical correlation in any of the scores used. Conclusion: The clinical outcome of treatment of the thoracic and lumbar burst fractures was not influenced by a greater or lesser degree of initial or residual kyphosis, regardless of the type of treatment.
\end{abstract}

Keywords: Spinal fractures; Lumbar vertebrae; Thoracic vertebrae; Kyphosis.

\section{RESUMO}

Objetivo: Avaliar a correlação entre cifose decorrente de fratura tipo explosão da coluna torácica e lombar e desfecho clínico em pacientes submetidos a tratamento conservador ou cirúrgico. Métodos: Foi realizado estudo retrospectivo, de corte transversal, com 29 pacientes que apresentavam fratura na coluna torácica e lombar tipo explosão tratados pelo Grupo de Coluna de hospital referência em trauma, entre os anos de 2002 e 2011. Os pacientes foram acompanhados em ambulatório por um mínimo de 24 meses. Todos os casos foram avaliados clinicamente, através dos questionários Oswestry, de qualidade de vida SF-36 e pela escala visual analógica (EVA) de dor. Também foram avaliados radiologicamente, através de exames radiográficos e tomográficos da coluna lombossacra, no momento da internação hospitalar e nos retornos ambulatoriais subsequentes, pelo método de Cobb para mensuração do grau de cifose. Resultados: Não houve correlação estatisticamente significativa entre o grau de cifose inicial e o desfecho clínico mensurado pela EVA e pela maioria dos domínios do SF-36, tanto nos pacientes tratados de modo conservador quanto nos tratados cirurgicamente. O questionário Oswestry demonstrou benefícios para os pacientes que receberam tratamento conservador $(p=0,047)$ em comparação com os tratados cirurgicamente $(p=0,335)$. A análise entre diferença de cifose inicial e final e cifose final isolada, em relação ao desfecho clínico, não apresentou correlação estatística em nenhum dos escores utilizados. Conclusão: O resultado clínico do tratamento das fraturas da coluna torácica e lombar tipo explosão não foi influenciado por um menor ou maior grau de cifose inicial ou residual, independentemente do tipo de tratamento.

Descritores: Fraturas da coluna vertebral; Vértebras lombares; Vértebras torácicas; Cifose.

\section{RESUMEN}

Objetivo: Evaluar la correlación entre la cifosis debido a fractura del tipo explosión de la columna torácica y lumbar y el resultado clínico en pacientes sometidos a tratamiento consenador o quirúrgico. Métodos: Estudio retrospectivo, transversal con 29 pacientes con fracturas de la columna torácica y lumbar del tipo explosión tratados por el Grupo de Columna Vertebral de un hospital de referencia en traumas entre los años 2002 y 2011. Los pacientes fueron seguidos en ambulatorio por un mínimo de 24 meses. Todos los casos fueron evaluados clínicamente por los cuestionarios Oswestry, calidad de vida SF-36 y escala visual analógica (VAS) del dolor. También fueron sometidos a evaluación radiográfica y por TC de la columna lumbosacra, en el momento de la hospitalización y durante el seguimiento ambulatorio por el método de Cobb para medir el grado de cifosis. Resultados: No hubo correlación estadísticamente significativa entre el grado de cifosis inicial y el resultado clínico medido por EVA y la mayoría de los dominios del SF-36, en ambos pacientes tratados conservadoramente y tratados quirúrgicamente. El cuestionario Oswestry mostró beneficios para los pacientes que recibieron tratamiento consenvador $(p=0,047)$ en comparación con el tratamiento quirúrgico $(p=0,335)$. El análisis de la diferencia entre la cifosis inicial y final y cifosis definitiva aislada en relación con el resultado clínico no mostró correlación estadística en ninguna de las puntuaciones utilizadas. Conclusión: El resultado clínico del tratamiento de las fracturas del tipo explosión de columna torácica y lumbar no fue influenciado por un mayor o menor grado de cifosis inicial o residual, independientemente del tratamiento.

Descriptores: Fracturas de la columna vertebral; Vértebras lumbares; Vértebras torácicas; Cifosis.

\footnotetext{
1. Hospital Ortopédico de Passo Fundo, Passo Fundo, RS, Brazil.
}

2. Universidade de Passo Fundo - Passo Fundo, RS, Brasil.

Study conducted in the Spine Group of Hospital Ortopédico de Passo Fundo, Passo Fundo, RS, Brazil. Correspondence: Rua Sete de Setembro, 817. Passo Fundo, RS, Brazil. 99010-121. rtisot@ hotmail.com 


\section{INTRODUCTION}

Most spinal fractures occur between $\mathrm{T} 11$ and $\mathrm{L} 4$, and around $14 \%$ to $17 \%$ are classified as the burst type. The susceptibility of this region is due to the loss of stabilization caused by the ribs and chest muscles, the transition between kyphotic thoracic and lordotic lumbar curvature, and the change in facet joint orientation, from coronal in the thoracic spine, to sagittal in the lumbar spine. ${ }^{1}$

Burst fractures of the thoracic and lumbar spine have a causal mechanism, which is axial compression on the vertebral body. Their radiological characteristics are retropulsion of bone fragment into the inside of the spinal canal and increased interpedicular distance. This type of fracture can be associated with varying degrees of traumatic spinal stenosis, vertebral body collapse, and local kyphosis. The thoracolumbar transition region is the most commonly affected site, ranging from $10 \%$ to $45 \%$ of cases. ${ }^{2-4}$ The most commonly used classification for burst thoracic and lumbar spine fractures is currently the one initially described by Magerl et a/ $/ 5$ and recently modified by Vaccaro et $a^{6}{ }^{6}$ This classification, which is adopted by the $\mathrm{AO}$ group, classifies fractures as subtypes $\mathrm{A} 3$ and $\mathrm{A} 4$.

The degree of local kyphosis presented by the fracture is used as an important factor for defining the therapeutic approach. In addition, some patients with burst fractures may develop progressive mechanical instability, with increased kyphosis, chronic dorsolumbar pain and neurological sequelae. ${ }^{7}$ Therefore, its treatment is widely discussed and still remains controversial.

The aim of this study is to assess the relationship between initial and final traumatic kyphosis and clinical outcome, in patients submitted to conservative and surgical treatment.

\section{MATERIALS AND METHODS}

A retrospective, cross-sectional study was conducted with 29 patients with thoracolumbar burst fractures treated by the Spine Group of a trauma reference hospital, between 2002 and 2011. It should be emphasized that only patients with normal neurological function were selected (Frankel E). ${ }^{8}$ The patients included in this study were observed in an outpatient setting, with a minimum follow-up of 24 months. All cases were clinically evaluated during follow-up, with the Short-Form 36 (SF 36) ${ }^{9}$ quality of life questionnaire was used in the validated version in Portuguese. The Oswestry ${ }^{10}$ questionnaire and visual analog scale (VAS) of pain were also applied.

Upon admission to hospital, all the patients underwent anteroposterior and lateral radiographic examinations of the spine, as well as a computed tomography (CT) scan in axial, sagittal and coronal sections. During outpatient follow-up, anteroposterior and lateral spinal $\mathrm{x}$-rays were routinely performed. All these tests were made available for research, through the Medical Archive and Statistics Service (SAME) of the aforementioned institution. The research project was authorized by the Ethics Committee of the University of Passo Fundo, RS, Brazil, under opinion number 682.269.

The fractures were classified as burst, according to the criteria described by Vaccaro et al, ${ }^{6}$ which subdivides these lesions into subgroups $A 3$ and $A 4$.

The measurement of initial post-traumatic and follow-up kyphosis was performed according to the Cobb ${ }^{11}$ method, using the upper and lower vertebra adjacent to the fractured vertebra in lateral $x$-ray.

Of the 29 patients assessed, 14 underwent surgical treatment and 15 conservative treatment. It should be emphasized that the criteria adopted for the indication of surgical treatment, in cases where neurological function was normal, was kyphosis greater than $30^{\circ}$, collapse of the vertebral body greater than $50 \%$, or narrowing of the spinal canal greater than $50 \%$. Some polytraumatized patients who did not meet the above criteria were also treated surgically, due to the need for early mobilization, in order to minimize the risk of thromboembolic events and lung infections. Patients treated surgically underwent arthrodesis with instrumentation on the vertebrae adjacent to the fracture, and patients submitted to conservative treatment used a Jewett brace for a period of 4 to 6 months.

For statistical analysis of this study, a significance level of 0.05
( $\alpha=5 \%$ ) was considered, and descriptive levels (p) below this value were considered significant and represented by $p<0.05$. The MannWhitney test, Spearman correlation analysis, and Wilcoxon signed-rank test were applied. Version 22.0 of the SPSS (Statistical Package for Social Sciences) program was used for the analysis, and to obtain the results.

\section{RESULTS}

The results were obtained according to: (a) demographic data; (b) relationship between initial kyphosis and clinical outcome; (c) relationship between final kyphosis and clinical outcome (d) relationship between mean initial and final kyphosis, and clinical outcome.

Demographic data: Twenty-two patients were male (75.9\%) and seven were female (24.1\%). As regards the etiology of the trauma responsible for the fracture, falls from a height were found to be the cause in 22 (75.9\%) cases, traffic accidents in 5 (17.2\%), and direct trauma in just $2(6.9 \%)$ cases.

In terms of the affected spinal segment, most cases occurred at the thoracolumbar transition (T12-L1), with 16 (55.2\%) cases. There were $11(37.9 \%)$ cases in the lumbar region (L2 to L5) and only 2 $(6.9 \%)$ cases in the thoracic region (T1 to T11).

As regards the recommended treatment, of the 29 patients studied, 14 (48.3\%) were treated surgically and 15 (51.7\%) conservatively. The average age at trauma was 46.52 years (median 48), ranging from 22 to 69 years.

b) The relationship between initial kyphosis and clinical outcome: Mean initial kyphosis in the patients treated conservatively was $11.3^{\circ}$, ranging from $-10^{\circ}$ to $28^{\circ}$. In the surgical treatment, mean initial kyphosis was $14.71^{\circ}$, ranging from $-4^{\circ}$ to $35^{\circ}$. Therefore, no statistically significant difference was observed between the mean initial kyphosis of patients treated conservatively and surgically $(p=0.446)$.

There was no statistically significant relationship between the degree of initial kyphosis and clinical outcome measured by the visual analogue scale (VAS) of pain in both the patients treated conservatively $(p=0.146)$ and those treated surgically $(p=0.503)$.

The clinical outcome assessed by the Oswestry questionnaire was better for the patients treated conservatively $(p=0.047)$ than for those treated surgically $(p=0.335)$.

It should also be emphasized that there was no statistically significant relationship between the degree of initial kyphosis and clinical outcome, represented by most of the domains of the SF-36 questionnaire, regardless of the recommended treatment. The relationship between the degree of initial kyphosis and the limitation due to physical aspects $(p=0.017)$ and mental health $(p=0.039)$ domains was statistically significant only in relation to conservative treatment, i.e., the clinical outcome was superior, in these domains, with conservative treatment. (Table 1)

c) Relationship between final kyphosis and clinical outcome: The mean final kyphosis, in the patients treated conservatively, was $17.87^{\circ}$, ranging from $-1^{\circ}$ to $40^{\circ}$. In the surgical treatment, mean final kyphosis was $16.57^{\circ}$, ranging from $-6^{\circ}$ to $36^{\circ}$.

However, no statistically significant difference was found between the mean final kyphosis of the patients treated conservatively and surgically $(p=0.773)$. (Figure 1$)$

There was no statistically significant relationship between the degree of final kyphosis and clinical outcome measured by the VAS scale, both in the patients treated conservatively $(p=0.403)$ and in those treated surgically ( $p=0.671$ ).

Regardless of the recommended treatment, clinical outcome, evaluated using the Oswestry questionnaire, presented no statistically significant difference between the patients treated conservatively $(p=0.215)$ and surgically $(p=0.450)$.

It should be also emphasized that there was no statistically significant relationship between the degree of final kyphosis and clinical outcome, represented by all the SF-36 domains, regardless of the recommended treatment. (Table 2 )

Relationship between mean initial and final kyphosis and clinical outcome: In the radiographic evaluation, there was a statistical difference between the values of initial kyphosis and final kyphosis in the patients 
Table 1. Correlation between initial kyphosis and subdivisions of SF-36, VAS and Oswestry.

\begin{tabular}{|c|c|c|c|c|}
\hline \multirow{2}{*}{ Variables } & \multicolumn{4}{|c|}{ Treatment } \\
\hline & Surgical & $\mathbf{p}$ & Conservative & $\mathbf{p}$ \\
\hline \multicolumn{5}{|l|}{ SF36 Domains } \\
\hline Functional capacity & 0.394 & 0.163 & -0.405 & 0.134 \\
\hline Limitations due to physical problems & -0.217 & 0.456 & $-0.603^{*}$ & 0.017 \\
\hline Pain & 0.366 & 0.198 & -0.362 & 0.185 \\
\hline General state of health & -0.228 & 0.433 & -0.195 & 0.487 \\
\hline Vitality & 0.254 & 0.381 & -0.398 & 0.142 \\
\hline Social aspects & -0.298 & 0.302 & -0.197 & 0.481 \\
\hline Limitations due to emotional aspects & 0.190 & 0.515 & -0.312 & 0.257 \\
\hline Mental health & -0.365 & 0.200 & -0.536 & 0.039 \\
\hline OSWESTRY & -0.278 & 0.335 & $0.519^{*}$ & 0.047 \\
\hline VAS & 0.196 & 0.503 & 0.394 & 0.146 \\
\hline
\end{tabular}

The correlation is significant when $p \leq 0.05$.

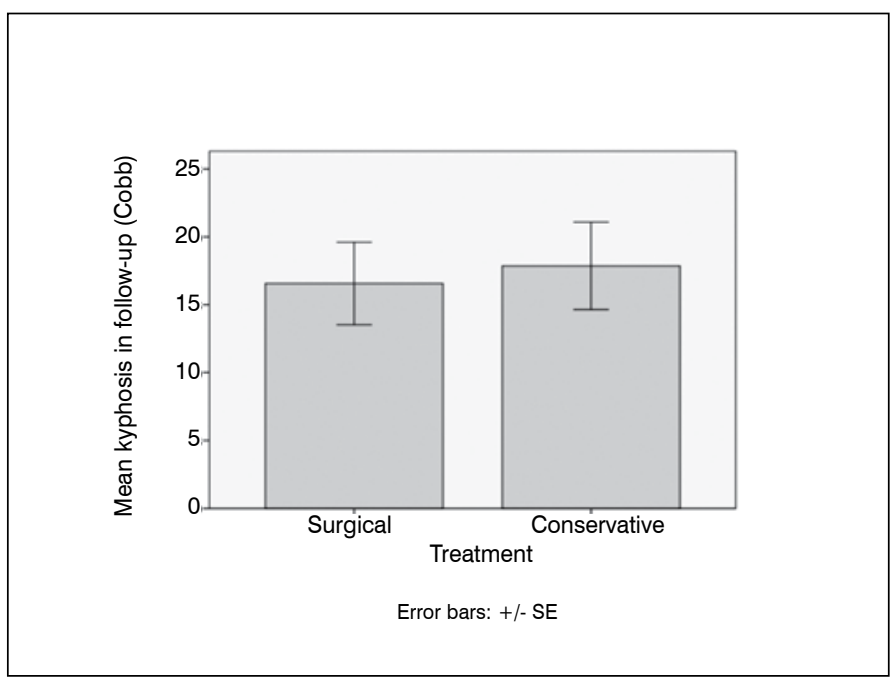

Figure 1. Mean final kyphosis (in follow-up) $(p \leq 0.05)$

treated conservatively $(p=0.008)$. In the patients treated surgically. However, this relationship was not evidenced $(p=0.489)$. (Figure 2$)$

The mean difference between initial and final kyphosis, in the patients treated conservatively, was $6.53^{\circ}$, ranging from $-10^{\circ}$ to $16^{\circ}$. In surgical treatment, the mean kyphosis difference was $1.86^{\circ}$, ranging from $-12^{\circ}$ to $17^{\circ}$. Therefore, a statistically significant difference was verified between the mean kyphosis difference of the patients treated conservatively and surgically $(p=0.057)$. (Figure 3 )

There was no statistically significant relationship between the degree of difference between initial and final kyphosis and clinical outcome measured by the visual analogue scale (VAS) of pain, both in the patients treated conservatively $(p=0.558)$ and in those treated surgically ( $p=0.610)$.

Clinical outcome, assessed by the Oswestry questionnaire, showed no statistically significant difference for both the patients treated conservatively $(p=0.578)$ and those treated surgically $(p=0.608)$, when the difference between initial and final kyphosis was evaluated.

There was no statistically significant relationship between the kyphosis difference and clinical outcome, represented by the SF-36 domains, regardless of the treatment administered $(p>0.05)$. (Table 3)
Table 2. Correlation between final kyphosis and subdivisions of SF-36, VAS and Oswestry.

\begin{tabular}{|c|c|c|c|c|}
\hline \multirow{2}{*}{ Variables } & \multicolumn{4}{|c|}{ Treatment } \\
\hline & Surgical & $\mathbf{p}$ & Conservative & $\mathbf{p}$ \\
\hline \multicolumn{5}{|l|}{ SF36 Domains } \\
\hline Functional capacity & 0.248 & 0.392 & -0.410 & 0.129 \\
\hline Limitations due to physical problems & -0.140 & 0.632 & -0.402 & 0.137 \\
\hline Pain & 0.240 & 0.240 & -0.279 & 0.315 \\
\hline General state of health & -0.228 & 0.433 & -0.160 & 0.568 \\
\hline Vitality & 0.104 & 0.724 & -0.353 & 0.197 \\
\hline Social aspects & -0.318 & 0.267 & -0.218 & 0.434 \\
\hline Limitations due to emotional aspects & 0.311 & 0.280 & -0.187 & 0.505 \\
\hline Mental health & -0.157 & 0.592 & -0.497 & 0.060 \\
\hline OSWESTRY & -0.220 & 0.450 & 0.340 & 0.215 \\
\hline VAS & 0.125 & 0.671 & 0.233 & 0.403 \\
\hline
\end{tabular}

*The correlation is significant when $p \leq 0.05$

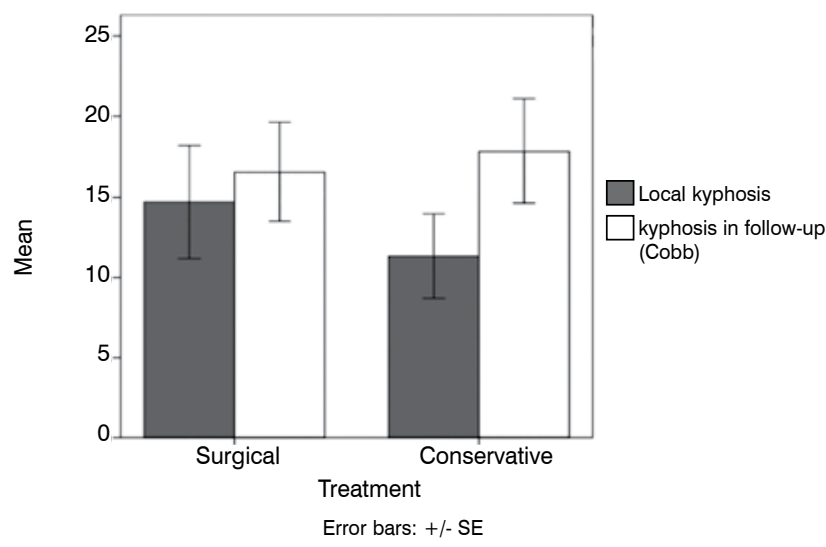

Figure 2. Initial and final kyphosis in the different treatments $(p \leq 0.05)$

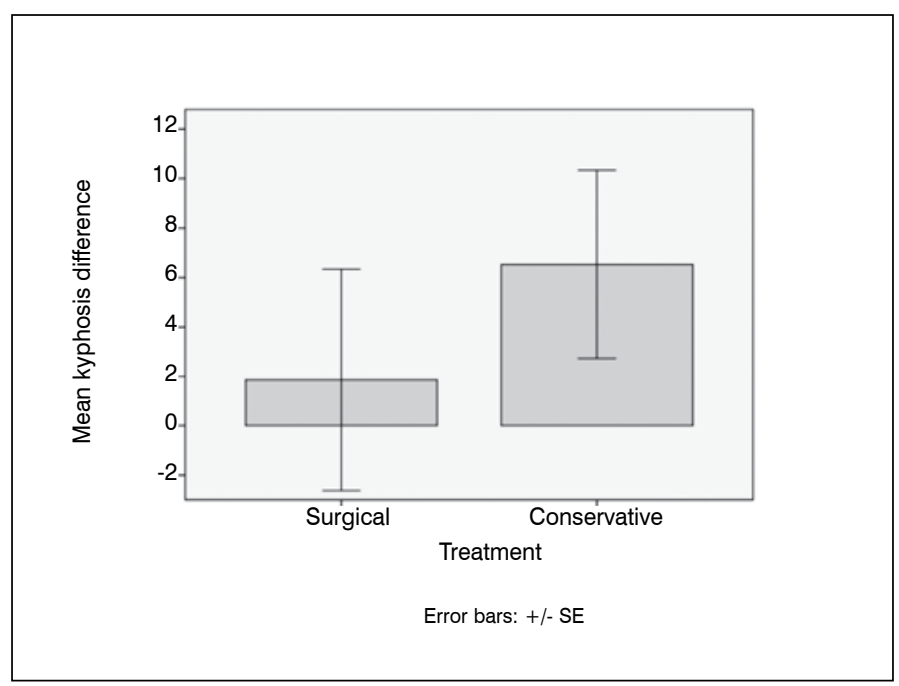

Figure 3. Mean kyphosis difference ( $p \leq 0.05)$. 
Table 3. Correlation between the difference of kyphosis and subdivisions of SF-36, VAS and Oswestry.

\begin{tabular}{c|c|c|c|c}
\hline \multirow{2}{*}{ Variables } & \multicolumn{4}{c}{ Treatment } \\
\cline { 2 - 5 } SF36 Domains & Surgical & $\mathbf{p}$ & Conservative & $\mathbf{p}$ \\
\hline Functional capacity & \multicolumn{4}{|c}{} \\
\hline Limitations due to physical problems & 0.163 & 0.578 & 0.168 & 0.549 \\
\hline Pain & -0.269 & 0.352 & 0.034 & 0.904 \\
\hline General state of health & 0.052 & 0.859 & -0.001 & 0.997 \\
\hline Vitality & -0.279 & 0.334 & -0.048 & 0.866 \\
\hline Social aspects & 0.038 & 0.897 & -0.103 & 0.715 \\
\hline Limitations due to emotional aspects & 0.133 & 0.650 & 0.126 & 0.654 \\
\hline Mental health & 0.390 & 0.169 & -0.103 & 0.715 \\
\hline OSWESTRY & 0.150 & 0.608 & -0.156 & 0.578 \\
\hline VAS & -0.149 & 0.610 & -0.164 & 0.558 \\
\hline
\end{tabular}

The correlation is significant when $p \leq 0.05$

\section{DISCUSSION}

The treatment of burst fractures of the thoracic and lumbar spine in literature is controversial. In general, surgical treatment is proposed for patients with associated neurological damage. The remaining doubt relates to the conduct to be applied for the patient to exhibit normal neurological function. Should we classify this fracture as unstable in order to justify a surgical indication? We must remember that exclusively bone-related instability, resulting from acute trauma, ceases to exist after fracture consolidation. The severity of burst fractures without associated neurological deficit, could manifest through the comminution of the fractured vertebral body, the presence of lamina fracture, increased kyphosis, or the collapse and narrowing of the spinal canal caused by the bone fragments from the fracture. ${ }^{12,13}$ But could the increase in local kyphosis, or its continuation after acute trauma, be related to the end result of the treatment?

Observational studies in patients with burst fractures of the thoracic and lumbar spine and normal neurological function have shown no difference in long-term functional outcomes, regardless of the type of treatment. ${ }^{14-16}$ Authors who advocate surgical treatment justify it by the good results obtained, the shorter hospitalization time, early mobility, better correction of kyphosis, and the possibility of direct decompression of the spinal canal, which would prevent a possible late neurological deterioration. ${ }^{17-18}$

In a prospective randomized study, Wood et $\mathrm{a} /{ }^{19}$ compared the outcomes of surgical and conservative treatment in 47 patients with burst thoracolumbar fracture (24 treated surgically and 23 with orthesis or plaster cast). Radiographic analysis showed similar results in relation to kyphosis (mean $12.9^{\circ}$ upon admission and $17.2^{\circ}$ in follow-up). In our analysis, mean initial kyphosis in patients treated conservatively was $11.3^{\circ}$, and in follow-up, $17.9^{\circ}$, while mean initial kyphosis in the patients treated surgically was $14.7^{\circ}$, and in follow-up, $16.6^{\circ}$.

The average progression of the deformity found in the study by Avanzi et al, ${ }^{20}$ which assessed 17 patients for 34.7 months, ranging from $15-118$ months, was $1.8^{\circ}$. In their retrospective study, Tropiano et a ${ }^{21}$ assessed 41 patients treated conservatively with hyperextension plaster cast, and reported mean initial kyphosis of $3.4^{\circ}$ and mean final kyphosis of $4.6^{\circ}$, showing a mean increase in the deformity of $1.2^{\circ}$. After conservative treatment of 20 patients with orthoses, Cantor et a $/^{22}$ reported $19^{\circ}$ initial kyphosis, $20^{\circ} \mathrm{fi}$ nal kyphosis and $1^{\circ}$ mean progression of deformity, while Chow et al, ${ }^{23}$ in their case series of 24 patients treated conservatively with plaster cast or orthoses, reported mean progression of deformity of $2.3^{\circ}$, with initial kyphosis of $5.3^{\circ}$ and final kyphosis of $7.6^{\circ}$. Shen et al, ${ }^{24}$ in their study with 38 patients treated with orthoses, reported initial kyphosis of $20^{\circ}$ and final kyphosis of $24^{\circ}$, presenting mean deformity progression of $4^{\circ}$. A similar result was verified by Mumford et al, ${ }^{25}$ in which the mean deformity progression was $3.87^{\circ}$, with initial kyphosis of $16.24^{\circ}$ and final kyphosis of $20.12^{\circ}$. Even after a long follow-up of up to 41 years, Moller et a/26 found results similar to those of other authors, reporting initial kyphosis of $15.4^{\circ}$ and final kyphosis of $18.5^{\circ}$, evidencing mean deformity progression of $3.1^{\circ}$. To compare, the radiographic evaluation of our series showed results similar to those of other authors, with mean kyphosis progression of $6.54^{\circ}$, mean initial kyphosis of $11.33^{\circ}$, and final kyphosis of $17.87^{\circ}$

Comparing the radiographic findings with the outcome of the recommended treatment, few studies are found in the literature. Andress et $a /,{ }^{27}$ in a study with a retrospective series of 50 patients with burst fracture, treated surgically, failed to demonstrate a relationship between the radiographic findings and the functional outcomes with regards to pain reported by the patients, in the long term. Likewise, Lakshmanan et al, ${ }^{28}$ attempted to correlate the recurrence of kyphosis and its functional implications in 26 patients treated surgically. No statistical relationship could be found. In another study, of the meta analysis type, Gnanenthiran et $a^{29}$ evaluated four clinical trials on the treatment of burst thoracolumbar fracture, totaling 79 patients (41 with surgical treatment and 38 with conservative treatment). The average follow-up ranged from 24-118 months. They found differences between the groups in relation to improvement of kyphosis, in the operated group. However, surgical treatment did not show any superiority in relation to pain and rate of return to work. They concluded, therefore, that surgical treatment of burst thoracolumbar fractures without neurological deficit can improve residual kyphosis, but does not improve pain, besides being associated with higher rates of complications and costs. Yi et $a^{30}$, in another meta-analysis, found similar results. In our series, we found no statistically significant results, when correlating the radiographic findings with the clinical outcome (SF-36, Oswestry and VAS).

With regards the standardization of treatment to be established in this type of injury, it is suggested that a greater number of studies be conducted. However, these should be prospective, with larger samples, and with a selection protocol that allows the inclusion of patients with more equivalent injuries. Until then, the desire of the spinal surgeon to devise a better definition of therapeutic conduct will continue, also requiring common sense and the individualization of each case at the time of indicating treatment.

\section{CONCLUSION}

It is concluded that the clinical outcome of the treatment of burst thoracic and lumber spine fractures was not influenced by a lesser or greater degree of initial or residual kyphosis, regardless of the type of treatment recommended.

In the follow-up radiographic evaluation, kyphosis was worse in the patients submitted to conservative treatment, as compared to the patients treated surgically. However, no relationship was found between the degree of initial kyphosis or final residual kyphosis, and clinical outcome, both in the patients treated conservatively and in those treated surgically.

All authors declare no potential conflict of interest concerning this article. 


\section{REFERENCES}

1. Knight RQ, Stornelli DP, Chan DP, Devanny JR, Jackson KV. Comparison of operative versus nonoperative treatment of lumbar burst fractures. Clin Orthop Relat Res. 1993:(293):112-21

2. Denis F.The three column spine and its significance in the classification of acute thoracolumbar spinal injuries. Spine (Phila Pa 1976). 1983;8(8):817-31.

3. Kraemer WJ, Schemitsch EH, Lever J, McBroom RJ, McKee MD, Waddell JP. Functiona outcome of thoracolumbar burst fractures without neurological deficit. J Orthop Trauma. 1996;10(8):541-4.

4. Thomas KC, Bailey CS, Dvorak MF, Kwon B, Fisher C. Comparison of operative and nonoperative treatment for thoracolumbar burst fractures in patients without neurological deficit: a systematic review. J Neurosurg Spine. 2006;4(5):351-8.

5. Magerl F, Aebi M, Gertzbein SD, Harms J, Nazarian S. A comprehensive classification of thoracic and lumbar injuries. Eur Spine J. 1994;3(4):184-201

6. Vaccaro AR, Oner C, Kepler CK, Dvorak M, Schnake K, Bellabarba C, et al. AOSpine thoracolumbar spine injury classification system: fracture description, neurological status, and key modifiers. Spine (Phila Pa 1976). 2013;38(23):2028-37.

7. Tisot RA, Avanzi O. Fratura da coluna vertebral tipo explosão na área da cauda equina: correlação entre função neurológica e alterações estruturais no canal vertebral. Acta Ortop Bras.2008;16(2):85-88.

8. Frankel HL, Hancock DO, Hyslop G, Melzak J, Michaelis LS, Ungar GH, et al. The value of postural reduction in the initial management of closed injuries of the spine with paraplegia and tetraplegia. I. Paraplegia. 1969;7(3):179-92.

9. Ware JE Jr, Sherbourne CD. The MOS 36-item short-form health survey (SF-36). I. Conceptual framework and item selection. Med Care. 1992;30(6):473-83.

10. Fairbank JC, Couper J, Davies JB, O'Brien JP. The Oswestry low back pain disability questionnaire. Physiotherapy. 1980;66(8):271-3

11. Harrison DE, Cailliet R, Harrison DD, Janik TJ, Holland B. Reliability of Cobb and Harrison posterior tangent methods: which to choose for analysis of thoracic kyphosis. Spine (Phila Pa 1976). 2001;26(11):E227-34.

12. Tisot RA, Avanzi O. Laminar fractures as a severity marker in burst fractures of the thoracolumbar spine. J Orthop Surg (Hong Kong). 2009;17(3):261-4.

13. Whitesides TE Jr. Traumatic kyphosis of the thoracolumbar spine. Clin Orthop Relat Res. 1977;(128):78-92.

14. Denis F, Armstrong GW, Searls K, Matta L. Acute thoracolumbar burst fractures in the absence of neurological deficit: a comparison between operative and nonoperative treatment. Clin Orthop Relat Res. 1984;(189):142-9.

15. McEvoy RD, Bradford DS. The management of burst fractures of the thoracic and lumbar spine. Experience in 53 patients. Spine (Phila Pa 1976). 1985;10(7):631-7.

16. Defino HLA, Fuentes ARR, Remondi PH, Ballim EC. Tratamento conservador das fraturas da coluna toracolombar. Rev Bras Ortop. 2000;35(8):301-8.
17. Avanzi $\mathrm{O}$, Chih $L Y$, Meves R. Avaliação do tratamento cirúrgico da fratura toracolombar com material de terceira geração. Rev Bras Ortop. 2002;37(6):226-32.

18. Dickson JH, Harrington PR, Erwin WD. Results of reduction and stabilization of the severely fractured thoracic and lumbar spine. J Bone Joint Surg Am. 1978:60(6):799-805.

19. Wood K, Buttermann G, Mehbod A, Garvey T, Jhanjee R, Sechriest V, et al. Operative compared with nonoperative treatment of a thoracolumbar burst fracture without neurological deficit. A prospective, randomized study. J Bone Joint Surg Am. 2003:85(5):773-81.

20. Avanzi O, Chih LY, Meves R, Caffaro MFS, Bueno RS, Freitas MMF. Fratura toracolombar tipo explosão: resultados do tratamento conservador. Rev Bras Ortop. 2006;41(4):109-15.

21. Tropiano P, Huang RC, Louis CA, Poitout DG, Louis RP. Functional and radiographic outcome of thoracolumbar and lumbar burst fractures managed by closed orthopaedic reduction and casting. Spine (Phila Pa 1976). 2003;28(21):2459-65.

22. Cantor JB, Lebwohl NH, Garvey T, Eismont FJ. Nonoperative management of stable thoracolumbar burst fracture with early ambulation and bracing. Spine (Phila Pa 1976). 1993;18(8):971-6.

23. Chow GH, Nelson BJ, Gebhard JS, Brugman JL, Brown CW, Donaldson DH. Functional outcome of thoracolumbar burst fractures managed with hyperextension casting or bracing and early mobilization. Spine (Phila Pa 1976). 1996;21(18):2170-5.

24. Shen WJ, Shen YS. Nonsurgical treatment of three-column thoracolumbar junction burst fractures without neurologic deficit. Spine (Phila Pa 1976). 1999;24(4):412-5.

25. Mumford J, Weinstein JN, Spratt KF, Goel VK. Thoracolumbar burst fractures. The clinical efficacy and outcome of nonoperative management. Spine (Phila Pa 1976). 1993;18(8):955-70.

26. Moller A, Hasserius R, Redlund- Johnell I, Ohlin A, Karlsson MK. Nonoperatively treated burst fractures of the thoracic and lumbar spine in adults: a 23- to 41-year follow-up. Spine J. 2007;7(6):701-7.

27. Andress HJ, Braun $H$, Helmberger T, Schurmann M, Hertlein $H$, Hartl WH. Long-term results after posterior fixation of thoraco-lumbar burst fractures. Injury.2002;33(4):357-65.

28. Lakshmanan P, Jones A, Mehta J, Ahuja S, Davies PR, Howes JP. Recurrence of kyphosis and its functional implications after surgical stabilization of dorsolumbar unstable burst fractures. Spine J. 2009;9(12):1003-9.

29. Gnanenthiran SR, Adie S, Harris IA. Nonoperative versus operative treatment for thoracolumbar burst fractures without neurologic deficit: a meta-analysis. Clin Orthop Relat Res. 2012:470(2):567-77.

30. Yi L1, Jingping B, Gele J, Baoleri X, Taixiang W. Operative versus non-operative treatment for thoracolumbar burst fractures without neurological deficit. Cochrane Database Syst Rev. 2006;(4):CD005079. 